\title{
Authentic Material and Automaticity for Teaching English
}

\author{
Widyastuti \\ State Institute for Islamic Studies (IAIN) Salatiga \\ Widyastuti.jati@yahoo.com \\ DOI: http://dx.doi.org/10.18326/rgt.v10i1.83-100
}

\section{ENGLISH ABSTRACT}

This article discusses how to make students of Science Education in first year feel interesting in English lesson, understanding the text well and can communicate English fluency. It has been suggested that Authentic Material and Automaticity Theory not only creates a friendly and fun condition in teaching reading but helps students to study comprehensibly so they are able to understand the text, structure, vocabulary easily, read fluently and they also can communicate in English. The authentic material can make the teaching learning process fun and eliminate boring because the topics and materials can be found in internet so it will be more visually and interactive. Automaticity theory can solve the problem of students who must memorize words that make them feel boring and forget the words soon. The other benefit is the students can exposure the real language being used in a real context and stimulate studens'idea, encouarage them to relate themselves with real-life experiencesThese strategies can make the students understand easily and enjoy the teaching learning process. By combining authentic material and automaticity strategies for teaching English in science education, will develop readers (students) to become fully competent and fluent.

Key Words: Authentic material, Automaticity theory, Teaching English

\section{INDONESIAN ABSTRACT}

Artikel ini membahas bagamana agar mahasiswa di Tadris IPA tahun pertama tertarik dan dapat memahami teks berbahasa inggris dengan baik selain itu juga dapat berkomunikasi dalam Bahasa Inggris dengan lancar. Authentic Material dan Automaticity Theori tidak hanya menciptakan suasana pembelajaran membaca yang nyaman dan menyenangkan tetapi membantu mahasiswa untu belajar secara menyeluruh sehingga mereka dapat belajar bacaan, tata Bahasa dan kosa kata dengan mudah selain itu mereka bisa membaca dan berkomunikasi dalam Bahasa inggris dengan lancar. Authentic Material membuat proses belajar mengajarnya menjadi menyenangkan dan menghilangkan rasa bosan Karena topik dan materinya bisa diambil di internet sehingga bisa dilihat dan lebih interaktif. Authomaticity Theory dapat mengatasi rasa bosan mahasiswa yang harus menghafal kosa kata sulit dan cepat lupa. Keuntungan lain adalah mahasiswa dapat menggali bahasa yang sesungguhnya dalam konteks nyata ,merangsang dan mendorong ide mahasiswa ,untuk mengkaitkan dengan kehidupan nyata. Dengan demikian strategi ini akan membuat mahasiswa mudah memahami dan merasa nyaman dalam proses be;ajar mengajar. Dengan menggabungkan dua strategi, yaitu authentic material dan automatiy theory dalam 
pembelajaran Bahasa Inggris di Tadris IPA, akan meningkatkan kecakapan dan kelancaran mahasiswa dalam Bahasa Inggris.

Kata Kunci: Materi otentik, Teori otomatisasi, Pengajaran Bahasa Inggris

\section{INTRODUCTION}

Reading means different things to different people, for some it is recognizing written words, while for others it is an opportunity to teach pronunciation and practice speaking. However, reading always has purpose.

The reason for reading depends very much on the purpose for reading. Reading can have three main purposes, for survival, for learning or for pleasure. Reading for survival is considered to be in response to our environment, to find out information. In contrast reading for learning is considered to be the type of reading done in classroom and is goal oriented, while reading for pleasure is something that does not have to be done.

Reading is central to the teaching and learning language. It is also one of the more difficult aspects of language to teach well. Teaching reading has to be one of toughest tasks a teacher faces. We all know that reading skills are essential to students' success on standardized tests and college entrance exams. In their ability to communicate orally and in writing and in nearly all other areas of life.

Indeed there are many different teaching methods which people today purport which do not focus on solely teaching reading. There are many different ways of making reading a little more interesting.

This article tries to adress the often neglected aspect of enjoying and motivating students in the process of studying reading especially in the first year students of science departement IAIN Salatigabeside that this paper will discuss the need of teachers to teach the proper reading strategies to help the students understand the text easily.

The sources of authentic materials that can be used in the classroom are infinite, but the most common are newspapers, magazines, TV programs, movies, songs and literature. One of the most useful is the Internet. Whereas newspapers and any other printed material date very quickly, the Internet is continuously updated, more visually stimulating as well as 
being interactive, therefore promoting a more active approach to reading rather than a passive one.

Automaticity theory of learning emphasizes the importance of training at the associative stage, where learners come to coordinate individual skills in more varied, complex tasks which display automaticity and fewer breakdowns in mental processing and overloads of working memory. The process is lengthy one, students will get eventually and are capable if given the correct support. Patience is vital to the successful implementation of theory.

Automaticity refers to the ability to perform complex skills with minimal attention and conscious effort. Automaticity is essential for higher-order thinking such as skilled reading and writing because important sub-skills must be performed accurately, quickly and effortlessly.

\section{Reason for Using Authentic Material and Automaticity Theory in The Classroom}

When considering the use of authentic materials, Widdowson wrote:

"It has been traditionally supposed that the language presented to learners should be simplified in some way for easy access and acquisition. Nowadays there are recommendations that the language presented should be authentic" (Widdowson 1990:67).

The use of authentic material in teaching and learning activity is not new. Authentic material can include TV show, radio, news broadcast, documentaries, movies, photograph, art work, adverticement, brocure etc. Authentic material focuses on helping students eliminate the feeling of failing or other negative association they may have toward learning activity. One of the important principles of communicative language teaching is that authentic language should be used in instruction whenever possible (Omaggio- Hadley, 1993).

Martinez (2000) summarized several benefits of using authentic materials.

1. By using authentic material, students are exposed to real discourse, as in videos of interview with famous people where intermediate students listen for general idea.

2. Using authentic materials in the classroom is once outside the "safe", controlled language learning environment, the learner will not encounter the artificial language of the classroom but the real world and language how it is really used. 
3. Keep students informed about what is happening in the world, so they have an intrinsic educational value.

4. As language changge is reflected in the materials so that students and teachers can keep abreast of such changes.

5. Reading texts are ideal to teach/practice mini-skill such as scanning, eg students are given a news article and asked to look for specific information. Also, teachers can have students practice some of the micro-skills of listening . eg basically students listen to news reports and they are asked to identify the name of countries, famous people etc.

6. Different authentic material such as books, articles, newspaper and soon contain a wide variety of text type and language styles not easily found in conventional teaching materials. Thus it can help students extend their vocabulary and help memorize them in a number of meaningful recycling.

7. Authentic material can encourage learning for pleasure because they are likely to contain topic of interest to learners, especially if students are given the chance to have a say about the topics of kinds of authentic material to be used in class.

8. Authentic material drawn from periodicals are always up to date and constantly being updated. (www.intelegentbusiness@ pearson Education 2005)

As result, learners will keep high motivation and interesting in language teaching through these meaningful interaction with the material. Nunan (1999).

\section{Authentic Material Selection Criteria}

The definition of authentic material is the materials that have been produced to fulfill some social purpose in the language community. ( Peacock 1997). The purpose is to stimulate students'idea, encouarage them to relate themselves with real-life experiences and develop topics in ways that articulate their ideas and aplicate them correctly. Tomlinson \& Masuhara ( 2010: 400 ) states that "Authentic materials are designed not to transmit declarative knowledge about the target language but rather to provide an experience of language in use.

The basic consideration for selecting authentic material is trying to pick topic that are relevant and of interest to the students. Providing materials that are both practical and aplicable that can help students to relate themselves with real-life experiences. 
Another aspect which need to be considered is how to make the exercise fun and aplicable to help the students think ahead and prepare themselves about the topic.The exercise provides the perfect opportunity to challenge students' critical thinking skills. Students also gain valuable learning experience in data interpretation.

It can be concluded that authentic materials bridge the gap between classroom language use and real life language use by bringing familiar linguistic situation and materials right into the classroom. When teachers use authentic materials, they are in fact helping students to make a comfortable learning to fulfill some social purpose in language community.

\section{How to Choose Authentic Material Text}

Authentic texts have been defined as “...real-life texts, not written for pedagogic purposes" (Wallace 1992:145) They are therefore written for native speakers and contain "real" language. They are "...materials that have been produced to fulfil some social purpose in the language community." (Peacock (1997).

The sources of authentic materials that can be used in the classroom are infinite, but the most common are newspapers, magazines, TV programs, movies, songs and literature. One of the most useful is the Internet. Whereas newspapers and any other printed material date very quickly, the Internet is continuously updated, more visually stimulating as well as being interactive, therefore promoting a more active approach to reading rather than a passive one. From a more practical point of view, the Internet is a modern day reality, most students use it and for teachers, there is easier access to endless amounts of many different types of material. From a even more practical/economical point of view, trying to obtain authentic materials abroad can be very expensive, an English paper/magazine can cost up to 3-4 times the price that it usually is and sometimes is not very good. Often by having unlimited access in the work place, looking for materials costs nothing, only time.

Authentic materials should be the kind of material that students will need and want to be able to read when travelling, studying abroad, or using the language in other contexts outside the classroom. Authentic materials enable learners to interact with the real language 
and content rather than the form. Learners feel that they are learning a target language as it is used outside the classroom. When choosing materials from the various sources, it is therefore worth taking into consideration that the aim should be to understand meaning and not form, especially when using literary texts with the emphasis being on what is being said and not necessarily on the literary form or stylistics. Nuttall gives three main criteria when choosing texts to be used in the classroom suitability of content, exploitability and readability. Suitability of content can be considered to be the most important of the three, in that the reading material should interest the students as well as be relevant to their needs. The texts should motivate as well as. Exploitability refers to how the text can be used to develop the students' competence as readers. A text that can not be exploited for teaching purposes has no use in the classroom. Just because it is in English does not mean that it can be useful. Readability is used to describe the combination of structural and lexical difficulty of a text, as well as referring to the amount of new vocabulary and any new grammatical forms present. It is important to assess the right level for the right students.

The "authentic" presentation, through the use of pictures, diagrams, photographs, helps put the text into a context. This helps the reader not only understand the meaning of the text better but also how it would be used. A more "attractive" text will appeal to the student and motivate them into reading. It may seem to be a very superficial aspect but the appearance of any article is the first thing that the student notices. An "attractive" looking article is more likely to grab the reader's attention rather than a page full of type. Very often it is so easy to just download an article from the Internet and present the student a page full of impersonal print, without taking any of these factors into consideration.

\section{Automaticity Theory}

Automaticity Theory (AT) attempts to explain how people acquire skills as a function of the automaticity of operating processes. Schneider and Fisk (1983) explain the mechanisms of skill acquisition in terms of contrasting automatic and controlled types of cognitive and memory processing.

Automatic processing is a fast, parallel, fairly effortless process which is not limited by short-term memory capacity, is not under direct subject control and performs welldeveloped skilled behaviors. Automatic processing typically develops when subjects deal with 
the stimulus consistently over many trials....Controlled processing is characterized as a slow, generally serial, effortful, capacity limited, subject controlled processing mode that must be used to deal with novel or inconsistent information. (p. 120)

Schneider and Fisk (1983) also show how practice changes controlled processing into automatic processing. According to them, automatic productions are modular and will develop when the component processes are consistent. This modular processing system can be hierarchical, with the same module being one part of many different skills. The assumption is that there is an upper limit to human attention span. Practice, however, can make automatic productions relatively free of limited memory resources; thus there is no necessary limit to the number of automatic processes which can be active at the same time. Moreover, practice makes productions autonomous, reducing direct conscious control of the subject. This is a crucial stage on which it can be said that good and poor learners divide. Automaticity which has been acquired through effective, repeated practice makes it possible to process different stimuli at different stages simultaneously, as in something like a psychological and pyschomotor version of a complex production line. Schneider and Fisk (1983) illustrate this change of behavior in practicing a motor skill by describing the change in learning how to play the piano. At the novice level, performance is very slow, serial, and capacity limited. Controlled processing is in effect at this stage and the learner must allot much of finite attention capacity to each motor task. After substantial practice, however, the learner builds up a vocabulary of playable notes by consistently repeating each note in a given phrase thousands of times. As the automatic productions develop, the performer can speed up the responses, incorporate more complicated rhythm information, and begin to have sufficient capacity freed up and made available to attend to the patterns of notes, familiar scales and chords, and then finally onto entire sections in the music. Figure 1 shows the continuum of automatization adapted from Whitaker (1983, p. 199)

By way of comparison and contrast, Anderson (1995) perceives the development of skill acquisition as the development of problem-solving operators. He divides the processes into three stages; the cognitive stage, the associative stage, and the autonomous stage. He describes the general characteristics of each stage as follows: In the cognitive stage, learners commit to memory a set of facts relevant to the skill. Typically they rehearse these facts as they first perform the skill. The process is slow. The information they have learned amounts 
to a set of problem-solving operators for the skill. In the associative stage, the connections among the various elements required for successful performance are strengthened. Errors are detected and eliminated as well. Learners, by this time, have converted the verbal knowledge once memorized into procedural knowledge. In the autonomous stage, the procedure becomes more skilled, more automated, and more rapid. In becoming so, it requires fewer and fewer attentional resources. Learners also develop more complex skills in the direction of becoming more automated and requiring fewer processing resources. Anderson says, "it is the procedural, not the declarative, knowledge that governs the skilled performance" (p.274)

The models of skill acquisition described above show how people develop automaticity with practice, and they break down a complex process over time into understandable stages. In learning a foreign language, just as with other skill acquisition processes, we must start from an absolute beginning stage at which we have no language and must progress over time until we have acquired language proficiency. Ultimately, we hope to attain the stage where we can exert control over language well enough to allocate our attention to understanding and responding to the content of messages, to actual communication.

In real classroom, it is hard to see how the process of acquiring functional proficiency levels over stages is actually acknowledged. Reading, grammar, key vocabulary, typical expression, and language associated with communicative situation and functions, etc. for each isolated item, explanation and opportunities for practice activities are often given.

They need to free up their cognitive and memory resources by becoming fluent, automatic, and efficient at certain elements of processing in order to devote their mental resources to more involved, complex tasks of real communication and interaction. In short, they need to stick it out with some practice tasks until stages of automaticity have been reached. After practicing distinct skills until a fluency with them has been reached, learners then need to practice them in more integrative, less framed tasks. In so doing, they will also learn how to balance their attention span; their cognitive and memory resources can be more efficiently shared out to the various integrated parts of increasingly complex tasks. Taking this into consideration, we need to restructure the whole curriculum to incorporate language training adapted to the associative stage of Anderson's (1995) model. Figure 2 demonstrates a 
model which could be applied to the structuring of the formal language curriculum around the concepts of AT.

Therefore, to talk about automaticity in foreign language reading, we need to divide elements involved in the reading act into what can be automated and what cannot. Knowledge-driven operations such as intra textual perception, metacognition, and prior knowledge may work mainly as individual differences in learners' general reading skills developed. More importantly, these operations cannot be automated because they are constantly changing depending on the context and continue to require attention and effort. However, automaticity in text-driven skills may well free up memory and cognition for the type of fluent reading that requires constant attention and effort, and breakdowns in such skills can prove to be the "weakest link" in the entire reading process

\section{The Use of Authentic Reading Materials And Automaticity Theory In The Classroom}

One of the main ideas of using authentic materials in the classroom is to "expose" the learner to as much real language as possible. Even if the classroom is not a "real-life" situation, authentic materials do have a very important place within it. It has been argued that by taking a text out of its original context, it loses it authenticity:

"As soon as texts, whatever their original purpose, are brought into classrooms for pedagogic purposes they have, arguably, lost authenticity." (Wallace 1992:79)

Even if true, the learner is still exposed to real discourse and not the artificial language of course textbooks, which tend not to contain any incidental or improper examples. They also tend to reflect the current eaching trend. Authentic materials also give the reader the opportunity to gain real information and know what is going on in the world around them. More times than not, they have something to say, be it giving information, a review. They also produce a sense of achievement. Extracting real information from a real text in a new/different language can be extremely motivating, therefore increasing students' motivation for learning by exposing them to 'real' language (Guariento \& Morley 2001). They also reflect the changes in language use, (again something that does not occur in textbooks, which become very dated, very quickly) as well as giving the learner the proof that the language is real and not only studied in the classroom: 
"Authentic texts can be motivating because they are proof that the language is used for reallife purposes by real people." (Nuttall 1996:172)

The wide variety of different types of text means that it is easier to find something that will interest the learner and may even encourage further reading or reading for pleasure. An advantage of taking a complete newspaper or magazine into classroom, rather than photocopies of an article, is that students can actually choose what they want to read. The more the learner reads, the better a reader he will become, not only improving his language level but also confidence. In each stage of proficiency, the learners should be given sufficient training to reach a stage where they can read the material rapidly and accurately. The content of the material should be easy and concrete at first, gradually becoming more difficult and abstract. In general, reading material that uses typical, mature written English may contain more complicated sentence structures when compared with spoken material. Exposing students with graded, spoken materials in the early stage may give them opportunities to listen to texts with the basic sentence structures and help them to internalize and schematize the basic English sentence structures. Though the ultimate goal of most reading practices may be to comprehend the text, syntactic feature recognition should be emphasized particularly to the L2 or FL readers whose native language structures are very different from those of the target language. Otherwise, learners may depend too much on their background knowledge and so not pay enough attention to what is actually written in a text.

Definition of Automaticity is ability to respond or react without attention or conscious effort. Automaticity is defined as fast, accurate and effortless word, identification at the single word. (Hook, PE and Jones, S.D 2002). Automaticity is essential for higher -order thinking, such as skilled reading and writing because important sub-skills must be performed accurately, quickly and effortlessly. If reading subskills are performed automatically, then higher order aspects of the task such as comprehension, can be performed effectively.

When students become a truly automatic readers, they will look at a page and read on it sequence, without unnatural hesitation they will understand what those words mean on a subconscious level and won't even have to think about or give to much attention to them to absorb their meaning. Automaticity in reading requires a great deal of practice to be thoroughly installed in memory. 
Because the reading demands on our students are high, students with poor reading fluency can fall begin, so it is important to provide and use tools, including technology that can assist students in reading practice and improve their automaticity.

\section{Samples of Reading Lesson the Classroom Activities}

Readers process texts in two ways, either Top-Down or Bottom-Up. Bottom-up processing is when the reader builds up meaning by reading word for word, letter for letter, carefully scrutinizing both vocabulary and syntax. This is often associated with poor or slow readers, but can sometimes occur when the readers own schema knowledge is inadequate. TopDown processing is the opposite, where a global meaning of the text is obtained, through "clues" in the text and the reader's good schema knowledge. This is often associated with a good reader, who does not read word for word but quickly and efficiently. The most comprehensive description of the reading process are interactive models, "...in which every component in the reading process can interact with any other component... (Alderson 2000:18)", combining elements of both bottom-up and top down models. Reading is considered to be an interactive process (a conversation between writer/reader, even though the writer is not present) and for it to occur both processes are necessary, top-down to predict the meaning and bottom-up to check it. The two are therefore complementary ways of processing a text.

The sample of activity uses text for example about Heart and Circulation, lung, Kidney, blood, brain etcthe materials were downloaded from the Internet and then adapted.The researcher chooses this text with the following reasons, firstly any students find many difficulties, boring with the text, hopefully by using Authentic Material land Automaticity Theory, the students won't find any difficulties and boring but they will feel interesting and fun with the material. Secondly, it evokes imagination and provides materials that are both practical and applicable that can help students to relate themselves with their knowledge and experiences. Thirdly the exercises of the text provide perfect opportunity to challenge students' critical thinking skills. Fourthly, there some sub-topic of Heart and Circulation, for examples What is blood, what are blood groups, How does the heart work and so on so it motivate students study automaticity because they will get more practice and vocabulary related to the text. And finally, students can gain valuable learning experience. 


\section{First step Pre-reading (observation)}

The aim of this step is to get students interested and build out their impression to the topic. The question will guide the students to construct their idea related to the activity and the goal is to understand and use English in real life and automatically. It can be made more approachable byreviewing new vocabulary before reading, and then asking students to perform tasks that are within their competence, such as skimming to get the main idea or scanning for specific information, before they begin intensive reading. Recycling the same words learned before in numerous different contexts may reduce their study load and will also help them recognize words in future reading encounters.

The students are given occupation to read the text,the more the student reads, the better a reader he will become, not only improving his language level but also confidence because they can read automaticity.

According to Automaticity Theory this step is in the cognitive stage, learners commit to memory a set of facts relevant to the skill. Typically they rehearse these facts as they first perform the skill. The process is slow. The information they have learned amounts to a set of problem-solving operators for the skill. By practicing regularly and repeating practice every time the lecturer come, hopefully the learners will respond automatically and easily so the students won't feel difficulties and boring but they will feel fun with the material.

To combine authentic material and automaticity theory, teacher must use variety strategies and different strategies for different text.

The example of activities in pre- reading

1. Using the title, subtitles and division within the text to predict content and organization or sequence of information.

2. Pronunciation in group

3. Read paragraph, it can motivate students reading fluency (the ability to read text quickly, accurately and automatically)

Teach new vocabulary using multi- sensory approach ( graphic organizer, photograph or pictures) by using LCD to create deeper understanding The "authentic" presentation, through the use of pictures, diagrams, photographs, also helps put the text into a context. This helps the reader not only understand the meaning of the text better but also how it would be used. It 
will become more "attractive" step of reading that will appeal to the student and motivate them into reading.

1. Reviewing vocabulary or grammatical structure

2. Doing guided practice with guessing meaning from context or checking comprehension while reading.

3. Describing a pictures

4. Involve all students in the simulation

\section{Step 2: While-reading}

Teacher tries to encourage the students to be a flexible and active readers, the teacher alsoto promote a dialogue between reader and writer. In this step the teacher can develop the questions, clarify the content of the text, ask the students to summarize or visualize and monitor the understanding of the students. It can be done in a group. The teacher can control language learning environment and the students will get real world and language how is really used. In While-reading, in discussing the text, the items area about typically grammar points, key vocabulary, typical expressions, and the language associated with communicative situations and functions. For each item, explanation and opportunities for practice activities are given

The example of activities in While-reading

1. Put students in group of four or in a partner

2. Ask them to discuss the answers of the questions from the text

3. Ask students to skim the text to get a general sense

4. Engage students in some general discussion of the topic, making a brief notes on board about main ideas

5. Monitor their understanding

6. Activate schema

7. Do error correction

8. Keep track of what students are grasping easily and what they are having trouble understanding or comprehending.

9. Clarify and correct students when they give incorrect answers 


\section{Review activities}

In this step, it is hoped that the students participate with more interest and involvement, they also gain confidence and can use their sense-making instincts or their automaticity. Students need not to memorize words, because by recycling the same words learned before in numerous different contexts may reduce their study load and will also help them recognize words in future reading encounters. The other benefit of automaticity is the students have the ability to read words without decoding, it means students reading allow them to read words fluently so that they can concentrate on comprehending the text.

\section{Step 3: Post-reading}

Post-reading strategies provide students away to summarize reflect and questions what they have just read.

The example of post reading activities

1. Assign them in different job for example summarize what they have read and draw picture or graphic organizer what they read.

2. Ask students to return to the statements and to make notes from what they have discovered in their text that may confirm or change their opinion.

3. Assign a relevant reading task to a small group so that students can practice using the features of the text to locate information and help them understand and remember what they read.

4. The teacher brings an English language newspaper/magazine to class and has students read the text and underline every instance of the present perfect aspect or passive tense, then copy them all in their note book.

5. The teacher uses on 'inauthentic' text from a published course book which was contrived specifically to practice reported speech and then discuss other waysin which the speakers could have said the same thing using different language.

6. The teacher asks students to use the internet to research about the pictures that show about the function of heart, lungs, brain or kidney then create a short information about the picture. 
7. If the students find difficulty in understanding the text from internet, the teacher can edit or simplify the text and if the passage is too long, the teacher can shorter the text and make lexically easier

By using the method of Authentic material and automaticity, the students will get four skills, in receptive reading they will study text by skimming, scanning, looking at text organization (paragraphing, topic sentences), listening for gist and listening for specific information. In productive speaking the students discuss on issues arising from the text or role play based on the scenario, and use the article as model responding in writing.

\section{CONCLUSION}

The use of authentic material in the classroom of science education students in IAIN Salatiga benefiting from exposure to real language being used in real context. Other aspects with proved positive when using authentic materials were that they are highly motivating, giving sense of achievement when understand and encourage further reading. For developing reading, the most useful resource is the internet, beside easily accessible.

Theory of Automaticity derived from the word automatic, automaticity is a key importance for developing readers to become fully competent and fluent. It means being able to recognize and process information without really thinking about it in conscious level. Something that human being is not born with but rather develop as they continue to learn when applied to reading. Automaticity is the ability to look at words and read them aloud without thinking.

Automaticity is very important to students of Science education because if our students achieving automaticity in reading is not only their becoming effective readers but becoming effective all -around learning. The majority students make a shift from "learning to read" to " reading to learn" Effective reading comprehension requires not only accurate reading and fluent reading school also automatic skill that allow them to easily comprehend what they are reading. Automaticity Theory can improve the teaching reading process because the students are able to coordinate individual skills in more complex task, leading to independence in communicating ability. 


\section{REFERENCES}

Alderson, J.C. \& Urquhart, A.H. (1984) Reading in a Foreign Language London, Longman

Alderson, J.C. (2000) Assessing Reading Cambridge, C.U.P.

Anderson, N.J. (1999) Exploring Second Language Reading - Issues and Strategies Canada, Heinle \& Heinle

Breen, M.P. (1985) Authenticity in the language classroom Applied Linguistics 6/1 pp60-70

Brumfit, C.J. \& Johnson, K. (1979) The Communicative Approach to Language Teaching Oxford, O.U.P.

Carrell, P.L., Devine, J. \& Eskey, D.E. (Editors) (1988) Interactive Approaches to Second Language Reading Cambridge, C.U.P.

Fumiko Yoshimura (2000) Automaticity Theory and EFL in Japan .Literacy Across Cultures. Spring/summer $4 / 1$

Goodman, K (1988) The Reading Process in Carrell, P.L., Devine, J. \& Eskey, D.E. (Editors) (1988) Interactive Approaches to Second Language Reading Cambridge, C.U.P. pp1121

Guariento, W. \& Morley, J. (2001) Text and Task Authenticity in the EFL Classroom in ELT Journal 55(4), pp 347-353

Hook.PE and Jones, SD (2002) The important of Automaticity and Fluently for Efficient Reading Comprehension. International Dyslexia Association Quarterly news Letter Perspective, winter, 2002, vol 8, no 1 page 9 -

Martinez, A.G. (2002) Authentic Materials: An Overview on Karen's Linguistic Issues http://www3.telus.net/linguisticsissues/authenticmaterials.html

Nuttall, C. (1996) Teaching Reading Skills in a foreign language (New Edition) Oxford, Heinemann

Peacock, M. (1997) The Effect of Authentic Materials on the Motivation of EFL Learners in English Language Teaching Journal 51, pp 2 
Richard, J.C. (2001) Curriculum Development in Language Teaching Cambridge C.U.P Samuels, SJ \& Flor, RT (1999) The importance of automaticity for developing expertise in reading. Reading \& Writing Quarterly, 13.107-121

Senior, R (2005) Authentic Responses to Authentic Materials in English Teaching Professional 38, pp71 